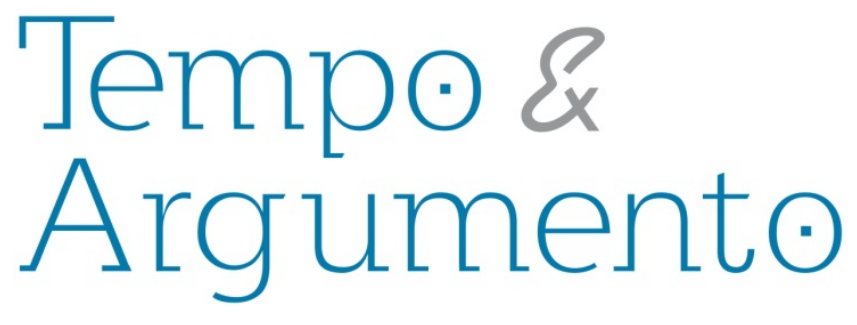

\title{
Humor e política nas caricaturas de Aluísio Azevedo
}

\begin{abstract}
Resumo
O objetivo deste artigo é refletir sobre as caricaturas políticas de Aluísio Azevedo (1857-1913), publicadas em O Fígaro, em 1876, e em O Mequetrefe, em 1877. Nesses desenhos, o humor gráfico e a influência positivista e anticlerical da imprensa do final do século XIX dão o tom das estratégias visuais contra a monarquia e em defesa da república. Entre a busca de um paraíso perdido e a consolidação de um futuro republicano e nacionalista, desenha-se a tentativa de estabelecer a soberania de um povo caracterizado em suas diferentes faces. As representações do Brasil e do povo brasileiro assumem um olhar romântico e idealizado na figura heroica do índio e do mártir crucificado, pluralizando as críticas sobre o império, sobre a história e o próprio papel da arte.
\end{abstract}

Palavras-chave: AZEVEDO, Aluísio, 1857-1913; Caricatura; Humor gráfico.

\section{Marilda Lopes Pinheiro Queluz}

Doutora em Comunicação e Semiótica pela Pontifícia Universidade Católica de São Paulo -

PUC-SP. Professora da Universidade

Tecnológica Federal do Paraná - UTFPR. Brasil pqueluz@gmail.com

\section{Para citar este artigo:}

QUELUZ, Marilda Lopes Pinheiro. Humor e política nas caricaturas de Aluísio Azevedo. Revista Tempo e Argumento, Florianópolis, v. 8, n. 18, p. 134 - 153. maio/ago. 2016.

\author{
DOI: $10.5965 / 2175180308182016134$
}

http://dx.doi.org/10.5965/2175180308182016134 


\title{
Humor and politics in the caricatures by Aluísio Azevedo
}

\begin{abstract}
This article aims to think through the political caricatures by Aluísio Azevedo (1857-1913), published in O Fígaro, in 1876, and in O Mequetrefe, in 1877. In these drawings, graphic humor and positivist and anticlerical influence of the press in late 19th century set the tone of visual strategies against the monarchy and in defense of the republic. Between the search for a paradise lost and the consolidation of a republican and nationalist future, the attempt to establish the sovereignty of a population characterized by its various faces is drawn. The representations of Brazil and the Brazilian people take a romantic and idealized look through the heroic figure of an Indian and a crucified martyr, pluralizing pieces of criticism on the empire, history, and the very role of art.
\end{abstract}

Keywords: AZEVEDO, Aluísio; 1857-1913; Caricature; Graphic Humor.

\section{Introdução}

O objetivo deste artigo é refletir sobre as estratégias visuais construídas nas paródias sobre a monarquia e a república, presentes nas caricaturas de Aluísio Azevedo. Para isso, delimitou-se o foco em uma charge publicada em O Fígaro, de 1876, e quatro charges de 0 Mequetrefe, de 1877, que são emblemáticas e são frequentemente citadas em estudos sobre os desenhos desse caricaturista (MÉRIAN, 1988; MAGNO, 2012). Na tentativa de perceber como a caricatura dialoga e, ao mesmo tempo, ajuda a construir o imaginário político do final do século XIX, este artigo analisa o modo como as representações do país e do povo pluralizam o olhar sobre o império, sobre a história e sobre o próprio papel da arte. 


\section{As estratégias da caricatura}

Considerando a mais antiga tradição da caricatura impressa, humor e política sempre caminharam lado a lado, convivendo intimamente nas litografias soltas e nas revistas ilustradas. Foi especialmente na Europa setecentista que se fortaleceu, a cada página, a vocação combativa e militante da charge. Em 1789, na França, já se comentava o grande poder de influência que os desenhos e as gravuras possuíam sobre os corações humanos: "eram vistos como tendo esse forte impacto porque eram percebidos como algo que falava diretamente aos sentidos e às emoções do povo" (GOLDSTEIN, 1989, p. 2).

Segundo Gombrich (2007), a caricatura, tal como a conhecemos hoje, teria surgido no século XVII, no ateliê dos irmãos Carracci, pela experimentação estética e a pesquisa do grotesco, retratando tipos populares e personalidades. Para o autor, "a invenção da caricatura-retrato pressupõe a descoberta teórica da diferença entre semelhança e equivalência" (GOMBRICH, 2007, p. 290). Caminha-se, assim, por outra via do conhecimento, que "se dá pela capacidade de avizinhar elementos descontínuos no tempo sobre um mesmo espaço. Nesse sentido, rir é um modo de relacionar o que está em contraste, mas que ainda não tínhamos conseguido pôr em relação" (PINHEIRO, 1994, p. 38).

As associações e substituições entre formas e traços exagerados criam relações de semelhança envolvendo aspectos psicológicos, valores sociais e culturais, aproximando diferentes contextos históricos. Talvez aí esteja a potência expressiva da caricatura como estratégia e arma de combate, além de crítica à política e seus representantes. Exemplos emblemáticos do desenvolvimento da caricatura política encontram-se na Inglaterra do século XVIII, como as gravuras de Hogarth (1697-1764), e nas lutas revolucionárias francesas, do final do século XVIII e início do século XIX, como os trabalhos de Daumier (1808-1879). “Em épocas de grande insegurança e temor, as formas de linguagem capazes de mobilizar a comicidade e o humor tornam-se particularmente atraentes, pois o riso ajuda a libertar o medo" (MOTTA, 2006, p. 13). 
Junto com esse amadurecimento da caricatura, intensificam-se os mecanismos de censura e perseguição. De acordo com Kenneth Rivers (1991), a caricatura é sempre subversiva, na medida em que oferece ao leitor textos "deformados", que requerem interpretação criativa, acabando por afastá-lo do hábito de ler passivamente. Para o autor, os "leitores que experimentam a interação com a caricatura estão menos inclinados a aceitar um texto de forma inquestionável. Daí porque os políticos odeiam as caricaturas [...] Um público que pode ler entre as linhas não é facilmente oprimido" (RIVERS, 1991, p. 230).

Ainda que nem sempre o riso provocado seja o da desordem e da transgressão, o humor gráfico propõe deslocamentos, aborda outros pontos de reflexão.

O surgimento do desenho de humor permitiu maior aproximação das classes subalternas em relação à política. A caricatura ajuda a traduzir os eventos, conflitos e grandes personagens políticos para a linguagem popular, tornando tais temas mais palatáveis para indivíduos iletrados e/ou socialmente excluídos (MOTTA, 2006, p. 18).

Desse modo, abre-se espaço para a opinião do leitor e sua consequente coautoria na interpretação dos fatos, na reconstrução dos significados. Trata-se de uma “convivência estabelecida entre o enunciador" do discurso e o "leitor capaz de transcender a literalidade para vislumbrar, justamente por meio das marcas aí instauradas, as significações ao mesmo tempo sugeridas e escondidas por esse espaço significante" (BRAIT, 1996, p. 31).

Na releitura dos fatos jornalísticos e das notícias, a caricatura apresenta inversões nas quais os acontecimentos são revistos como uma afirmação e uma negação da história a um só tempo, constituindo-se, a cada leitura, como "uma arma ao alcance de todos [...] ele destrói ou desfaz os simulacros, desconfigura ou reconfigura às avessas as imagens" (LANDOWSKI, 1995, p. 66).

Os caricaturistas são, antes de tudo, leitores de jornais e revistas, leitores da política. O processo criativo dá-se a partir das notícias, de um fato ou de um contexto discursivo imediato para manter o diálogo com seus traços e seus enunciados verbais, como um discurso sobre outro discurso, traduzindo a linguagem jornalística para uma 
crônica visual, estabelecendo uma opinião e um modo de reler as realidades que circulam pelas mídias.

Os desenhos satíricos, com traços exagerados e deformados, provocam o estranhamento, o riso, e funcionam como uma maneira de enfraquecer o adversário político. Essa estratégia de utilizar o traço caricato para zombar, ironizar o outro, tanto pode estar a serviço da revolução, do progresso, da liberdade, como pode reiterar o status quo, com um tom conservador, moralista, autoritário. Trata-se de um recurso que tem sido usado tanto pela imprensa de direita quanto pela de esquerda (MOTTA, 2006, p. 21).

A caricatura trabalha com figuras de linguagem como metáforas, metonímias, símbolos de poder para representar o Estado, a luta política. Vale-se de um repertório de imagens clássicas, mitológicas e religiosas para fazer alusão aos acontecimentos contemporâneos. Busca alegorias do passado para traduzir o presente. A presença do povo constitui-se entre generalizações, tipos característicos e estereótipos. Para simular uma linguagem mais abrangente e criar aproximação com um maior número de leitores, os desenhistas apropriam-se e colocam em diálogo temas e linguagens vindos de outras formas de expressão artísticas e culturais, como o teatro, a música popular, a literatura, a poesia, a pintura.

\section{Aluísio Azevedo e a imprensa do final do século XIX}

O Segundo Império investiu na imagem de um Brasil progressista, transformado pela paisagem técnica em meio à exuberância da natureza, guiado pelos conhecimentos e novos artefatos vindos de países vistos como civilizados, ainda que tensionado pelas contradições sociais: "o imperador correspondia-se com a fina flor da civilização europeia, interessava-se pela fotografia, observava as estrelas com os mais modernos instrumentos óticos [...] e governava um dos últimos países a manter a escravidão legal no Ocidente" (NEVES, 1991, p. 33). 
Em 1860, o café representava a metade do valor dos produtos importados (CHALHOUB, 2012) e trouxe várias mudanças como a introdução do trabalho livre e a vinda dos imigrantes. A produção cafeeira financiou a modernização da infraestrutura econômica e urbana, a organização e a participação do país em exposições universais. Havia uma dependência externa acentuada, principalmente do capital e dos produtos ingleses.

As construções públicas e simbólicas (fotos, exposições) traduzem a euforia com o progresso, enfatizando os aspectos tecnológicos dos empreendimentos públicos de cunho modernizador, como estradas de ferro, mapeamento do território e das riquezas do subsolo, edificações urbanas etc. (TURAZZI, 1995).

Nesse contexto de transformações técnicas, em 1858, foi inaugurada a primeira estrada de ferro no Rio de Janeiro; em 1861, foi construída a Estrada de Rodagem União Indústria, entre Juiz de Fora e Petrópolis; em 1872, tivemos a primeira linha de telégrafo; entre 1872 e 1874, instalou-se o cabo submarino ligando o Brasil à Europa; em 1880, iniciou-se a telefonia; a primeira usina hidrelétrica é de 1888; entre 1872 e 1895, definiu-se o tráfego das principais capitais, ampliaram-se as cidades, com iluminação a gás, transporte urbano a tração animal, serviços de água e esgoto (PAULA, 2012).

No universo dos periódicos ilustrados, o humor se destacou e contribuiu para a originalidade gráfica do gênero. Carlos Costa (2012) considera o período de 1860 a 1875 o momento em que os caricaturistas se apoderam das revistas semanais ilustradas, chegando ao auge de 1876 a 1878. Destacaram-se importantes periódicos, como Semana Ilustrada (1860-1876), de Henrique Fleiuss, Revista Ilustrada (1876-1898), de Angelo Agostini, O Mosquito (1869-1877), Ba-Ta-Clan (1867-1871), O Fígaro (1876-1878), O Mequetrefe (1875-1893), entre muitos outros. A caricatura dessa época experimentava o desenho acadêmico na rapidez do lápis litográfico, criando justaposições que questionavam as normas de representação, satirizando o conceito de arte como imitação da natureza, ampliando as fronteiras do real na pintura. Paródias e inversões de significados se delineavam nas críticas e interpretações dos acontecimentos oitocentistas. 
No Segundo Reinado, porém, a introdução da técnica litográfica como processo de reprodução permitiu a atualização técnica, aumentando a escala de reprodução da página impressa, mas, sobretudo, facilitando a integração entre texto e imagem na composição gráfica, o que constituía um dos maiores desafios para a empresa gráfica da época. Além disso, a imprensa ilustrada também começou a publicar imagens baseadas em fotografias, lançando as bases documentais da informação, próprias do fotojornalismo (KNAUSS, 2011, p. 12).

Aluísio Tancredo Gonçalves de Azevedo, mais conhecido por clássicos do naturalismo brasileiro, como O Mulato (1881) e O Cortiço (1890), "empunhou na juventude o lápis de desenhista e se consagrou como um dos mais promissores da nossa caricatura oitocentista" (MAGNO, 2012, p. 326). Nascido em São Luís, filho do vice-cônsul de Portugal no Maranhão, mudou-se aos 19 anos para o Rio de Janeiro, onde o irmão mais velho, Artur Azevedo, já era um famoso autor de comédias. Estudou na Academia Imperial de Belas Artes e deve ter tido contato com os traços algozes do português Rafael Bordalo Pinheiro (1846-1905) e dos italianos Ângelo Agostini (1843-1910) e Luigi Borgomainerio (1835-1876), os três grandes expoentes da caricatura da época. Com a morte súbita de Borgomainerio, em 1876, houve uma chance para Aluísio Azevedo começar a trabalhar em O Fígaro'1. Em seus desenhos, sente-se a forte influência de Bordalo Pinheiro, tanto nas soluções plásticas como nas temáticas. Ilustrou apenas 4 exemplares. Colaborou com O Mequetrefe $e^{2}$ de 19 de março de 1877 a 7 de setembro de 1877, e com a Comédia Popular de 6 de abril a $1^{\circ}$ de junho de 1878 (MÉRIAN, 1988).

O Rio de Janeiro que Aluísio Azevedo encontrou oscilava entre a capital que se queria elegante como Paris, racional como Londres e aquela pintada nas cores de uma palheta tropical, com fortes tons de exclusão e marginalidade:

\footnotetext{
${ }^{1}$ A folha ilustrada O Fígaro foi lançada em 1876, como uma espécie de continuação de A Vida Fluminense. Era impressa na Typographia Acadêmica e litografada na Litographia a Vapor de Angelo \& Robin. Teve a participação de desenhistas como Joseph Mill, Cândido Aragonez Faria e Pereira Neto. A última edição circulou em abril de 1878 (COSTA, 2012).

${ }^{2} \mathrm{O}$ Mequetrefe, de propriedade de E. J. Correa e Pedro Lima, foi lançado em 1875, pela Nova Typographia de J. Paulo Hildebrandt. Em seus dezoito anos de existência, publicou desenhos de Cândido Aragonez Faria, Pereira Neto, Joseph Mill. A redação contou com colaboradores como Artur Azevedo, Olavo Bilac, entre outos. O periódico propunha-se a criticar e satirizar os políticos e o clero (COSTA, 2012).
} 
A alta sociedade vivia à moda europeia. A vida social girava em torno da rua do Ouvidor e das ruas adjacentes, verdadeiro centro nevrálgico do Rio de Janeiro. Os dignatários do regime e os ricos comerciantes viviam nos palacetes de Santa Teresa e Botafogo [...] Mas essa sociedade representava a minoria da população do Rio de Janeiro. Seu poder, riqueza, modo de vida dependiam da exploração dos escravos e dos brancos pobres [...] Em 1874, entre uma população total de 300.000 habitantes, menos de 15.000 crianças cursavam as escolas e colégios públicos e privados. Os estudantes (medicina-farmácia-politécnica) não eram mais de mil [...] Quanto às moças, que representavam cerca de um terço dos alunos dos colégios e escolas, havia umas mil nas escolas privadas francesas e inglesas, e estavam ausentes das universidades (MÉRIAN, 1988, p. 98-99).

De acordo com o censo de 1872 , da população livre, $81,4 \%$ não sabiam ler e escrever. "Ao decompor os dados entre os sexos, via-se que $76,5 \%$ dos homens eram analfabetos; entre as mulheres a cifra subia para 86,5\%" (CHALHOUB, 2012, p. 44-46). Entre a população escrava, a taxa de alfabetização era de 0,08\%.

Com as consequências sociais e econômicas da proibição do tráfico negreiro, em 1850, e da Guerra do Paraguai (1865-1870), D. Pedro II passou a enfrentar uma crise da monarquia. A partir de 1870, crescem as influências do positivismo de Auguste Comte (1798-1857), do evolucionismo de Herbert Spencer (1820-1903) e do determinismo racial de Arthur de Gobineau (1816-1882), que iriam repercutir nos debates sobre nação e república. Em 1870, foi criado o Partido Republicano no Rio de Janeiro e, em 1873, foi fundado o Partido Republicano em São Paulo.

Os jornais e as revistas ilustradas tinham páginas repletas de severas críticas ao regime monárquico e à sociedade escravocrata, como campanhas pela abolição e por uma república que seria democrática e federativa, que foram fortalecidas pelas questões religiosas, militares e pelos ecos da Guerra do Paraguai. Mérian (1988, p. 109) ressalta que "a impressão geral transmitida pelas caricaturas é de que o Imperador não governa, deixando o país na anarquia, vítima das ambições dos partidos políticos, dos credos ingleses, de uma igreja corrupta".

Com a morte do pai, em 1878, Aluísio precisou voltar para o Maranhão e iniciou sua carreira como escritor, encontrando 
[...] no jornalismo uma das principais trincheiras de suas lutas contra a escravidão, o clero e o Império, defendendo o modelo republicano de governo. Em São Luís, o jovem Aluízio lança também os jornais de combate A Pacotilha e O Pensador, anticlericais e abolicionistas, enquanto o romancista se dedica à construção do painel naturalista (MAGNO, 2012, p. 329).

Em 1881, regressou ao Rio, vivendo profissionalmente como escritor de folhetins. Em 1896, abraçou a carreira diplomática e, em 1897, ajudou a criar a Academia Brasileira de Letras (ABL). Morreu em janeiro de 1913, em Buenos Aires.

\section{As representações do Brasil e do povo brasileiro}

Aluísio Azevedo tornou-se mais um dos que nutriam uma forte decepção com os rumos do país, com o regime imperial, preocupado em denunciar problemas como a fome, a febre amarela, os cortiços, a saúde pública, os abusos da polícia, a violência. Esse desencanto era alimentado pelo positivismo e pelo anticlericalismo que permearam a "batalha de símbolos e alegorias, parte integrante de batalhas ideológicas e políticas" (CARVALHO, 1990, p. 10). O ideal positivista condenava a monarquia em nome do progresso e considerava a república um modelo ideal de organização da pátria. Pregava a separação entre a igreja e o Estado, além de propor a garantia da ordem como condição para o progresso (CARVALHO, 1990).

A repercussão da Questão Religiosa (1873-1875) ${ }^{3}$ também gerou uma forte campanha anticlerical na imprensa. A Igreja era vista como um vício propagado pelo obscurantismo e fanatismo dos padres. Os artistas e intelectuais preferiam enaltecer a instrução, a ciência, o progresso e a higiene.

\footnotetext{
3 José Murilo de Carvalho explica que a Questão Religiosa, também chamada de Questão dos Bispos, referese ao episódio em que o bispo do Pará e o bispo de Olinda iniciaram uma "luta contra a interferência da maçonaria nas confrarias e ordens terceiras e contra a atividade de leigos maçons nas irmandades" (CARVALHO, 2012, p. 115). Em 1874, os dois foram processados e condenados à prisão pelo Supremo Tribunal de Justiça. Mesmo com a anistia dos bispos no ano seguinte, esse caso abalou ainda mais as bases da monarquia, que perdeu o apoio da Igreja.
} 


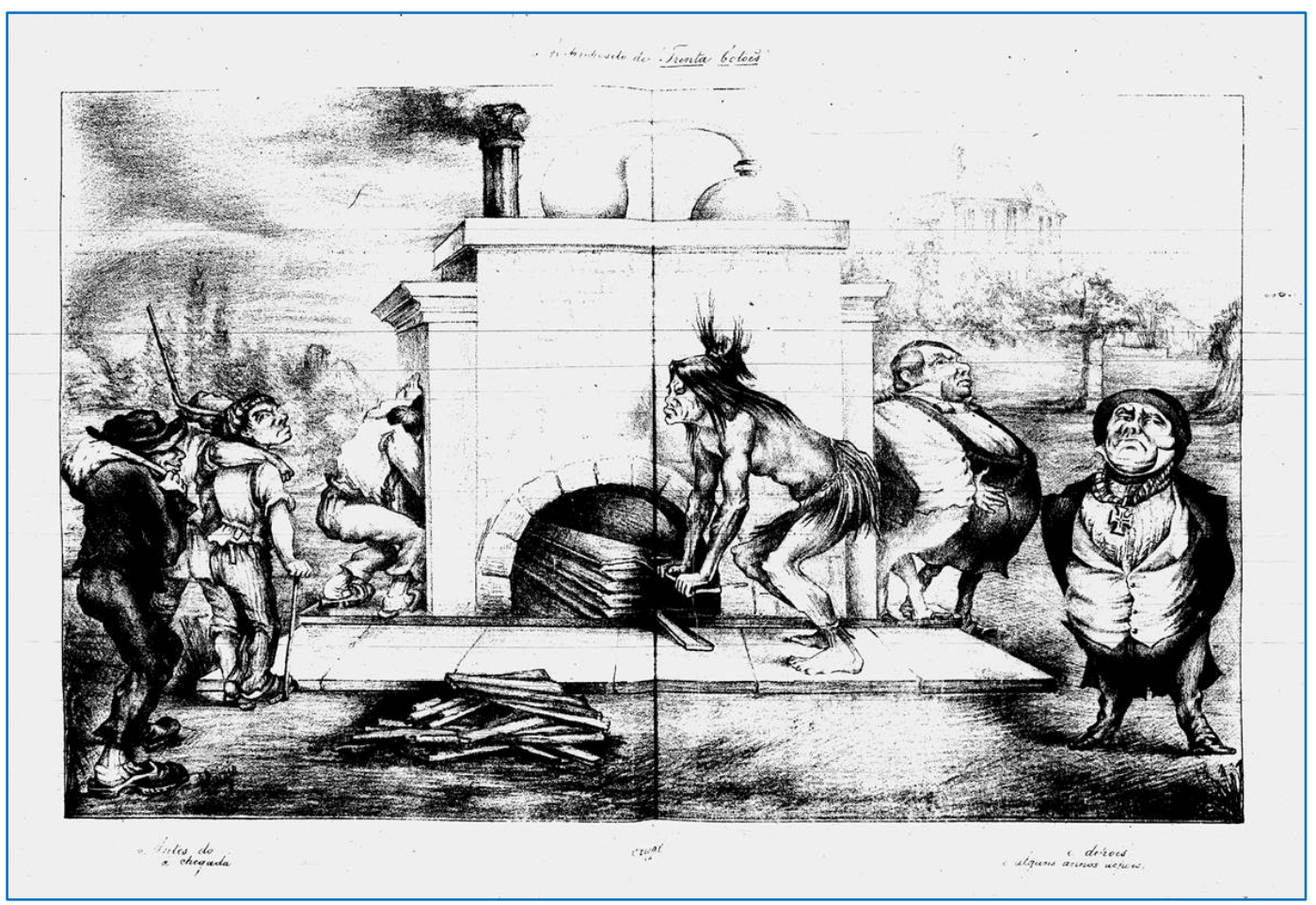

Figura 1 - ALUÍSIO AZEVEDO (1857-1913). “A propósito dos Trinta Botões”. Fonte: O Fígaro, n. 20 - 13/05/1876. Acervo digital da Biblioteca Nacional.

Mérian (1988, p. 115) afirma que a charge da Figura 1 refere-se à peça de Eduardo Garrido, "O Manuel Trinta Botões", que seria montada no Teatro São Pedro na mesma época. Por outro lado, Bordalo Pinheiro, já em 1875, havia criado a figura do "Manoel Trinta Botões", chegando mesmo a circular pelas ruas com um paletó com trinta botões para ironizar o modo como os portugueses bem-sucedidos se vestiam no Brasil (ARAUJO, 1996, p. 32).

Na Figura 1 há o que Mérian (1988, p. 116) chamou de "uma alegoria ao neocolonialismo português". No título "A propósito dos Trinta Botões”, ressalta-se a maneira pejorativa como eram vistos os emigrantes portugueses, especialmente os que enriqueciam e viviam falando mal dos brasileiros. A área central da imagem é ocupada por uma construção, uma espécie de máquina/caldeira, com detalhes de rigor técnico, movida a lenha, utilizando a força humana. Criam-se tensões entre ideais de civilização e natureza, na associação do índio com a paisagem urbana, fabril. Infere-se que ciência e tecnologia dependem do trabalho braçal, do esforço do habitante brasileiro. O índio é representado com uma altura maior que os demais personagens, musculoso e exercendo força, com o rosto marcado por traços grotescos, aproximando-se do estereótipo do 
selvagem, da expressão de máscara ritual ou animalesca. Sua presença se contrapõe aos pequeninos portugueses, à esquerda, que, ao entrar na máquina, transformam-se em gordos burgueses, com trajes e adereços que denotam riqueza, elegância, com poses e gestos - como o nariz empinado - que demonstram segurança e um ar de superioridade.

Mesmo que sua força esteja a serviço dos interesses portugueses, o índio não se curva, não abaixa a cabeça, mas os encara bravamente. O índio alimenta/mantém aceso o fogo e o imaginário do final do império. Há uma tentativa de sintetizar a história do país marcada pela exploração estrangeira e pela sobreposição dinâmica de dimensões espaçotemporais - natureza/civilização, passado/presente, pobreza/riqueza. A legenda reitera a passagem temporal, localizando como os portugueses chegam (antes) e como ficam alguns anos depois. As ambiguidades da caricatura tornam possível pensar a nação como a máquina ou uma fábrica que alimenta/engorda/enriquece os portugueses ou o índio como o povo do Brasil que produz energia e faz movimentar a riqueza sem se beneficiar dela.

Estudando os rótulos oitocentistas, Lívia Rezende (2005, p. 56-57) afirma que “era conveniente ao Império idealizar o índio como senhor das terras no passado e colocar-se como seu sucessor", construindo equivalências entre a raça branca europeia e o índio alegórico. Este se torna uma chave de leitura que associa as cidades tropicais ao ideal urbano europeu.

Se, por um lado, "encontrar a civilização europeia" constitui-se em objetivo manifesto do romantismo latino-americano, a mestiçagem, por outro, é pensada como fundamento de a América Latina se diferenciar em relação à Europa, na criação de uma quase "civilização nos trópicos". No programa de mestiçagem, pensado pelos românticos, em particular, o brasileiro, o negro, o escravo, fica em geral de fora, enquanto o índio, juntamente com a natureza, ambos são tomados como símbolos nacionais (AZEVEDO, 2010, p. 16).

O imperador passa a fomentar um projeto para promover a memória do país, escrever uma história heroica e assegurar a cultura brasileira, com a criação do Instituto Histórico e Geográfico Brasileiro (IHGB), em 1838, por exemplo. Nesse sentido, o romantismo se apresentava

[...] como o caminho favorável à expressão própria da nação recémfundada, pois fornecia concepções que permitiam afirmar a universalidade, mas também o particularismo, e portanto a identidade, 
em contraste com a metrópole, mais associada nesse contexto à tradição clássica. O gênero vinha ao encontro, dessa maneira, do desejo de manifestar na literatura uma especificidade do jovem país, em oposição aos cânones legados pela mãe-pátria, sem deixar de lado a feição oficial e palaciana do movimento (SCHWARCZ, 1998, p. 128).

Na busca de uma identidade brasileira, de um símbolo nacional, o índio parecia ser o modelo ideal de pureza, de coragem, de honra a ser resgatado. Segundo Schwarcz (1998, p. 136), foi nos decênios de 1850 e 1860 que o romantismo se consagrou e o indianismo alcançou o momento de maior prestígio, tornando-se presente não só na poesia e no romance, mas na música e na pintura.

A inspiração indígena invadiu as propagandas, os reclames, a iconografia política, as cerimônias oficiais, ao lado de elementos clássicos. As revistas de humor também se apropriaram desse símbolo, ora de maneira mais idealizada, como em Aluísio Azevedo, ora mais crítica e angustiada, como em Agostini e Bordalo Pinheiro. Apesar das marcas profundas da escravidão negra, o índio foi preferido como herói e representante do povo brasileiro, o verdadeiro "bom selvagem" de Rousseau, pelo menos nesse momento específico. Portanto,

[...] o romantismo no Brasil não foi apenas um projeto estético, mas também um movimento cultural e político, profundamente ligado ao nacionalismo [...] Fazendo da literatura um exercício de patriotismo, esse gênero ganhava lugar nos planos do Estado. A valorização do pitoresco da paisagem e das gentes, do típico em vez do genérico, encontrava no indígena o símbolo privilegiado. Representando a imagem ideal, o indígena encarnava não só o mais autêntico como o mais "nobre", no sentido de se construir um passado honroso. Por oposição ao negro, que lembrava a escravidão, o indígena permitia indicar uma origem mítica e unificadora [...] A natureza brasileira também cumpriu função paralela. Se não tínhamos castelos medievais, templos da Antiguidade ou batalhas heroicas para lembrar, possuíamos o maior dos rios, a mais bela vegetação. Entre palmeiras, abacaxis e outras frutas, apareciam caracterizados o monarca e a nação, destacando-se a exuberância de uma nação sem igual (SCHWARCZ, 1998, p. 140).

Essa tendência, esse desejo de se buscar a síntese, a pretensão de encontrar a “identidade" brasileira perseguiria ainda as gerações posteriores de caricaturistas, especialmente durante as primeiras décadas da República. 


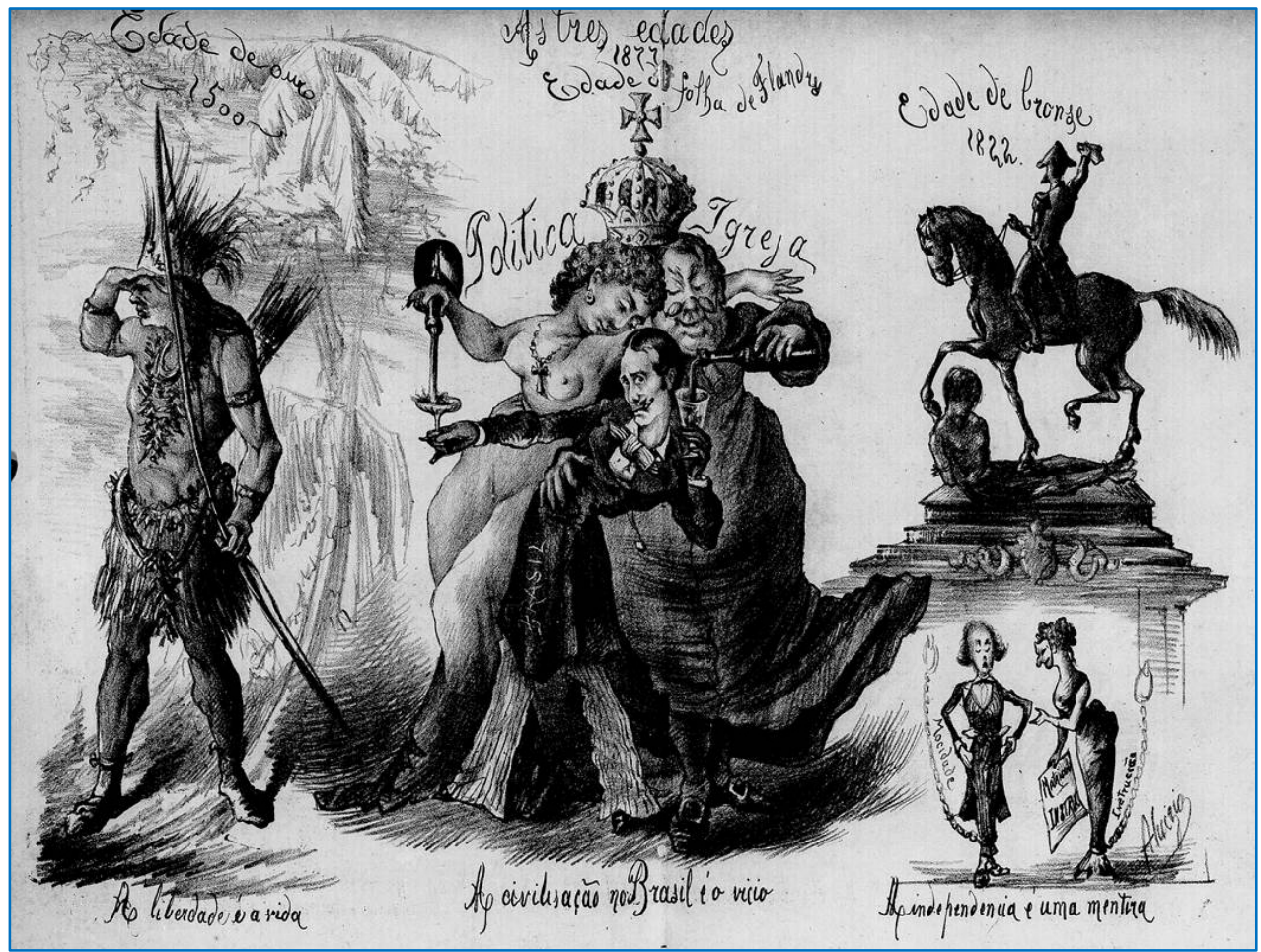

Figura 2 - ALUÍSIO AZEVEDO (1857-1913). "As três idades do Brasil”. Fonte: O Mequetrefe, n.94 - 19/03/1877 Acervo digital da Biblioteca Nacional.

Na charge "As três idades do Brasil" (Figura 2), crítica e nostalgia fundem-se no olhar sobre a situação brasileira. A Idade de Ouro (1500) é marcada pela presença do índio. Forte, altivo, musculoso, procurando algo no horizonte, sugere um guerreiro em prontidão, armado com seu arco e suas flechas, tentando avistar o que vem de longe. Configura-se uma sensação de perda. O índio volta-se para a esquerda (o passado?), para o início da história oficial do país, assim como outros elementos da imagem apontam a mesma direção: o braço do personagem central (Brasil), o cavalo, a personagem mascarada/instrução. Ao fundo, insinua-se a paisagem, em traços rápidos, lembrando a exuberância da natureza, as plantas icônicas na identificação das terras brasileiras. A frase "a liberdade é a vida" parece reiterar a busca do momento ideal. Constrói-se a noção da liberdade como existente apenas antes da vinda dos portugueses e o índio como o verdadeiro representante do povo brasileiro.

A imagem central remete ao presente, o ano de 1877, denominada Idade da Folha de Flandry ${ }^{4}$. A opulência da política e da igreja (representada pela caricatura do cônego

\footnotetext{
${ }^{4}$ Folha de ferro ou aço, batido ou laminado, de pouca espessura, banhada em estanho, com grande resistência ao tempo e aos agentes corrosivos. Muito usada para a fabricação de latas; é um metal mais barato, inferior. Disponível em https://pt.wikipedia.org/wiki/Folha_de_flandres, acesso em 21/06/2016.
} 
José Gonçalves Ferreira, diretor de O Apóstolo, um influente periódico católico), ressalta a magreza do homem em cuja roupa elegante e na moda lê-se "Brasil”. A política, representada como uma prostituta, jovem e bem nutrida, sinuosa e sensual, adornada apenas por um crucifixo, serve ao "Brasil" mais uma taça, em um gesto simultâneo ao do padre. A postura do país é forçada, toda torta, em ângulos, vergada. Trata-se de uma trindade em festa, animada, bem ao gosto do traço anticlerical. O enunciado verbal "A civilização no Brasil é o vício" reforça não apenas a imagem, mas reitera a ideia romântica da "idade anterior", de que os brasileiros só seriam livres no mundo idealizado dos nativos, longe da civilização europeia.

A "Idade do Bronze" nos traz o ano de 1822, identificado pelo momento da independência, o famoso suposto gesto de D. Pedro que se tornou apenas uma estátua, um monumento 5 para ser contemplado. O povo é representado por uma figura amarrada, sob as patas do cavalo, sem possibilidade de ação. Abaixo há uma cena onde uma mulher mascarada - a instrução - reconta a história à "mocidade" como uma farsa, reafirmada na frase "A independência é uma mentira". Ambos estão acorrentados, presos a uma liberdade meramente encenada. Aluísio parece colocar em questão o fato de que as manifestações artísticas mais diversas (escultura, desenho, pintura, teatro, literatura) ajudam a construir os grandes mitos e as farsas sobre o passado. Tem-se, assim, uma história do Brasil escrita em linhas tortuosas, com o presente cercado pelo passado, de forma não linear, conjugando tempos de modo a criar uma escala de valores, uma hierarquia em que a atualidade é o declínio da nação e a decadência do povo heroico.

A preocupação com os rumos da nação e o futuro da monarquia provocou muitos debates na imprensa e as caricaturas tentavam traduzir visualmente as críticas e os ideais republicanos, resultando em batalhas de representações, atravessadas pelas ambiguidades e contradições do próprio período. Luciano Magno (2012, p. 328) aponta um bom exemplo disso ao lembrar a resposta de $O$ Mequetrefe a uma caricatura publicada em O Fígaro.

\footnotetext{
5 Provável referência ao monumento em homenagem à proclamação da independência, encomendado por D. Pedro II. O projeto foi do artista brasileiro João Maximiano Mafra, com esculturas em bronze que foram executadas e fundidas em Paris por Louis Rochet. Foi inaugurado em 1862. A estátua equestre de D. Pedro I encontra-se sobre um pedestal ladeado por quatro alegorias/índios que simbolizam grandes rios brasileiros: São Francisco, Madeira, Amazonas e Paraná (KNAUSS, 2010).
} 


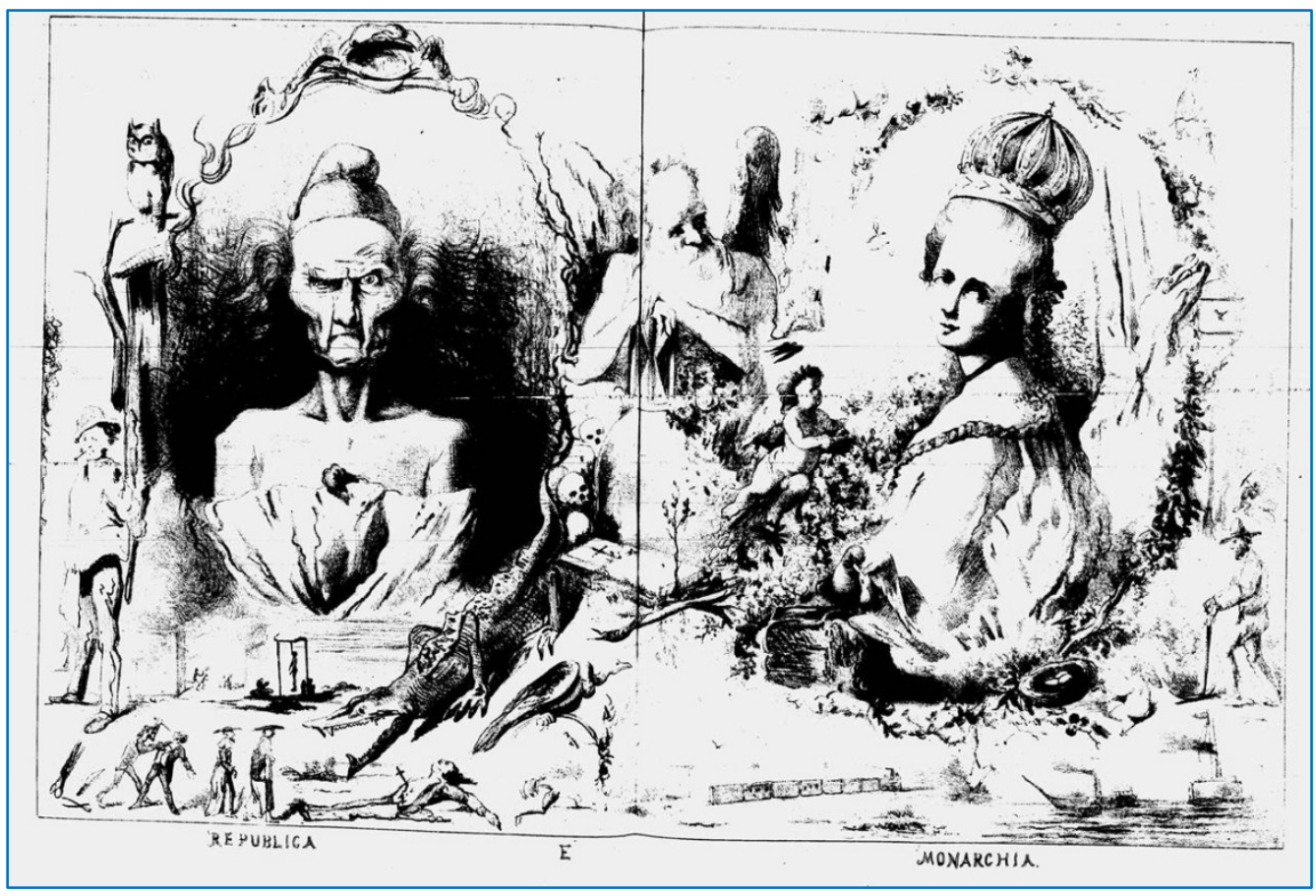

Figura 3 - Antonio Bernardes Pereira Neto ( - 1907)

Fonte: O Fígaro, n.83 - 28/07/1877 “A República e a Monarquia” Acervo digital da Biblioteca Nacional.

A alegoria feminina da República ${ }^{6}$ era muito frequente nas charges brasileiras do final do século XIX, com a presença do barrete frígio sobre a cabeça da figura feminina ou isolado. Na edição de O Fígaro, de 28 de julho de 1877, Antonio Bernardes Pereira Neto7 publica o desenho "República e Monarquia” (Figura 3), em que compara as duas formas de governo. À esquerda, vemos a República representada por uma mulher mais velha, bastante enrugada, despenteada, identificada pelo barrete frígio (símbolo dos libertos na Roma antiga), com um olhar desconfiado, uma expressão sisuda. A página é composta de alguns elementos simbólicos (caveiras, jacaré, coruja), elementos com conotação de agressividade (tesoura, faca), cenas de violência (uma pessoa sendo atacada, alguém enforcado, um índio morto por uma cruz), padres, um homem parado, fumando. Já a Monarquia é representada por uma jovem muito bem arrumada, elegante, ligeiramente de lado, com uma rica coroa, cercada por flores, pássaros, um anjo, um ninho com ovos,

\footnotetext{
${ }^{6}$ Sobre o uso da alegoria feminina para representar a República, ver CARVALHO, José Murilo de. A formação das Almas: o imaginário da República no Brasil. São Paulo: Companhia das Letras, 1990.

7 Antonio Bernardes Pereira Neto ( - 1907) era considerado um excelente portrait-chargista e retratista. Iniciou sua carreira em O Fígaro, em 1877, indo, em seguida para a Lanterna e O Mequetrefe, em 1878. Colaborou com desenhos em vários periódicos, como A Vespa, em 1885, e O Gryphus, em 1886. Ao final de 1888, substituiu Angelo Agostini na Revista llustrada, permanecendo ali por quase dez anos (MAGNO, 2012).
} 
um trem, navios, homens com o que parece ser uma enxada ou alguma ferramenta para trabalhar a terra. Entre as duas há um velho, um anjo, que se volta para a Monarquia e lembra a figura de D. Pedro II. Trata-se de uma representação bem complexa que dá margem para refletir sobre a coexistência de visões distintas sobre os caminhos da nação, contrapondo conquistas e lutas do passado e do presente com uma expectativa de um futuro já definhando.

Aluísio rebate essa imagem com uma versão mais agressiva na crítica à Monarquia.



Figura 4 - ALUÍSIO AZEVEDO (1857-1913).

Fonte: O Mequetrefe, n.108 - 06/08/1877. “Resposta ao Fígaro”. Acervo digital da Biblioteca Nacional. 
$\mathrm{Na}$ Figura 4, vemos a Monarquia acorrentada entre o partido conservador e o partido liberal, com os pés enraizados, contendo a palavra "clero". Parece estar sendo enforcada pelas pontas da bandeira acima de sua cabeça. A haste da bandeira sustenta um pássaro prestes a voar (a mocidade) e a jovem República segurando o progresso, apontando para longe. Na lateral esquerda há um recado: "Para defender o governo, só o Fígaro. Cada um sabe onde o sapato lhe aperta".

Essas duas caricaturas permitem pensar sobre as representações como uma arena de disputas simbólicas que constituem e são constituídas nas práticas sociais e nos discursos políticos veiculados pela imprensa.



Figura 5 - ALUÍSIO AZEVEDO (1857-1913).

Fonte: O Mequetrefe, n.97 - 10/04/1877. "E o povo... o povo também é rei, e rei como Jesus! Para beber o fel, para morrer na cruz". Acervo digital da Biblioteca Nacional. 
Além de usar a figura do índio, Aluísio também representou o povo brasileiro como o Cristo crucificado (Figura 5), revisitando uma cena bíblica para criticar o império. Aliás, esta metáfora era bastante recorrente nas caricaturas políticas. A imagem do povo é caracterizada pelo sacrifício, pelo sofrimento: ser brasileiro é morrer na cruz, tornar-se mártir, dar a vida. Mas é uma visão que se dá pela ambiguidade, pois, ao mesmo tempo, salienta que é rei, soberano, está acima de todos: dá a tônica à composição da página, delimita os espaços, divide a cena. É um corpo gigante que se ergue, embora cabisbaixo. Aluísio critica a política, os militares e a igreja simultaneamente. À esquerda, o imperador joga dados com o cônego José Gonçalves Ferreira, definido por duas circunferências (corpo e cabeça), sintetizado pela gordura. O imperador também é traçado em linhas simples e curvas. Ambos estão mais distantes, em proporções bem reduzidas. À direita, Duque de Caxias (1803-1880) aparece como o soldado que fere o povo. Os dois soldados são os únicos de olhos abertos e entreolham-se. O gesto forçado, brusco, meio estático de ambos contrapõe-se à espontaneidade do grupo à esquerda. De um lado curvas, de outro, retas - verticais e a diagonal; de um lado descontração, de outro, rigidez. Uma possibilidade de interpretação é a de que o povo está entre a indiferença, a sorte disputada na displicência do rei e do católico, e o autoritarismo e rigor dos militares. 0 enunciado verbal retoma a ambiguidade, afirmando que quem é rei é o povo, ainda que para ele só reste o fel e a cruz. O povo está muito mais próximo de Deus, sendo mais digno de ocupar o lugar de Cristo do que os padres. 




Figura 6 - ALUÍSIO AZEVEDO (1857-1913)- “A Sagrada Família - Paródia de Rubens”. Fonte: O Mequetrefe, n.99 - 25/04/1877. Acervo digital da Biblioteca Nacional.

Outra imagem que estabelece um trânsito entre o sagrado e o profano é apresentada como uma "paródia de Rubens". Aluísio Azevedo ironiza simultaneamente o império, a família imperial, as cenas bíblicas, a igreja e a própria arte. Inspira-se em uma cena de Rubens para questionar o espaço do sagrado e, ao mesmo tempo, criticar as várias fotografias da família real que circulavam no segundo império. "Como crônica visual, a caricatura também faz uso de imagens correntes na cultura visual estabelecida, colocando imagens conhecidas em diálogo" (KNAUSS, 2011, p. 11).

Aluísio parece sintetizar em um mesmo desenho todos os anseios de inverter a ordem, desestabilizar os conceitos dados como inabaláveis - política, religião, arte. Era 
tentador romper com o mito em torno do rei, com o ritual e os simbolismos que o acompanhavam. A caricatura, aliada a outras práticas culturais, nos ajuda a

[...] entender não apenas a articulação das imagens da realeza e sua manipulação, mas principalmente como os enunciados são incorporados pelos súditos, que alteram, valorizam, reduzem, selecionam, omitem os discursos veiculados (SCHWARCZ, 1998, p. 31).

A princesa Isabel, seu marido, o Conde D'Eu, e D. Pedro II recebem a inspiração do Cônego José Gonçalves Ferreira, representado como a pomba, símbolo do Espírito Santo, o suposto vértice de uma composição que não se enquadra na pirâmide clássica, no triângulo, mas é tumultuada, barroca, com muitos elementos. A expressão facial e o olhar desviado para cima dão o tom de zombaria que se reforça na figura de Caxias, mostrado como boi de presépio, muito sério, quase zangado. A criança, no centro da composição, pode ser associada à nação, ao futuro do país, mas, também, ao povo, inocente e indefeso. Aluísio propõe uma alegoria com personagens contemporâneos, bem conhecidos pelas mídias impressas. Religião e política são colocadas em um mesmo plano, aproximando seus valores mais enraizados. Ocorre uma dessacralização baseada na ironia quanto aos dogmas da igreja e aos ideários políticos, subvertendo crenças e propostas, papéis historicamente reconhecidos, anarquizando, retirando o poder do lugar habitual. A charge reelabora cenas presentes no imaginário popular. Religião e política são desenhadas como faces da mesma moeda, do mesmo discurso pelo poder.

\section{Considerações finais}

As charges, já no império, serviam "para compor uma certa 'dialética da ordem e da desordem', exprimindo a vasta acomodação geral que dissolvia os extremos ou, pelo menos, ajudava a diluir o significado da lei e da ordem, numa sociedade extremamente hierarquizada" (SALIBA, 1998, p. 306-307).

Os desenhos estavam contaminados pelos ideais positivistas e pelo anticlericalismo. O movimento anticlerical

[...] alimentou-se não só da filosofia positivista, mas também do jacobinismo; não somente do livre-pensamento, mas da maçonaria e do 
anarquismo; não somente da literatura universal, como o naturalismo, mas do simbolismo; não somente do desejo de construir o país, mas a região e a cidade (MARCHETTE, 1999, p. 90).

As caricaturas de Aluísio Azevedo, mais do que criticar o regime imperial, o papel da Igreja ou enaltecer a figura do índio e sublinhar o sofrimento do povo, propõem novos significados para os fatos, recontam a história pelo seu avesso, com os embates simbólicos e as interações do imaginário popular. Procuravam combater os dogmas, o despotismo, o colonialismo, o escravismo e o militarismo, mas, especialmente, o catolicismo. Natureza e civilização eram discutidas pela ironia e pela paródia, parecendo buscar uma estética que desse conta de conjugar o sublime e o grotesco.

A política é retratada como sedutora, perigosa, capaz de corromper e viciar as pessoas. As caricaturas ironizam o presente monárquico e apontam a República, jovem e promissora, como o caminho para o progresso e a liberdade. Entre a busca de um paraíso perdido e a consolidação de um futuro republicano e nacionalista, desenha-se a luta pela soberania de um povo caracterizado nas suas diferentes faces: o índio selvagem e feroz, escravizado pelos portugueses; o índio herói, o bravo guerreiro forjado nos padrões da escultura clássica grega, livre e corajoso, mas pertencente ao passado; o homem acorrentado ao pé da estátua equestre de D. Pedro I, sem conhecer a independência de seu país; o homem rico, elegante, frágil e facilmente dominado pela igreja e pela política; um pássaro pronto para voar; o jovem crucificado; a criança... Mesmo em uma visão romântica e idealizada, os traços de Aluísio Azevedo deixam entrever as contradições, as complexidades, os silêncios e as omissões sobre homens negros e mulheres negras, pobres, que faziam parte desse cenário, mas ficavam muito distantes do primeiro plano.

\section{Referências}

ARAUJO, Emanoel (Org.) Rafael Bordalo Pinheiro: o português tal e qual: da caricatura a cerâmica. São Paulo: Pinacoteca do Estado, 1996.

AZEVEDO, Sílvia Maria. Brasil em imagens: Um estudo da revista llustração Brasileira (1876-1878). São Paulo: Ed. UNESP, 2010. 
BRAIT, Beth. Ironia em perspectiva polifônica. Campinas, SP: Editora da UNICAMP, 1996.

CARVALHO, José Murilo de (Org.). A construção Nacional (1830-1889). Rio de Janeiro: Objetiva, 2012.

CARVALHO, José Murilo de. A formação das almas: o imaginário da República no Brasil. São Paulo: Companhia das Letras, 1990.

CHALHOUB, Sidney. População e sociedade In: CARVALHO, José Murilo de (Org.). A construção Nacional (1830-1889). Rio de Janeiro: Objetiva, 2012, pp. 37-81.

COSTA, Carlos. A revista no Brasil do século XIX. São Paulo: Alameda, 2012.

GOLDSTEIN, Robert Justin. Censorship of political caricature in nineteenth-century

France. Kent, Ohio: The Kent State University Press, 1989.

GOMBRICH, Ernst H. Arte e Ilusão. São Paulo: WMF Martins Fontes, 2007.

KNAUSS, Paulo. Introdução em Knauss, P.; Malta, M.; Oliveira, C. de y Velloso, M.P. (Org.) Revistas Ilustradas. Modos de ler e ver no Segundo Reinado. Rio de Janeiro: Mauad X; FAPERJ, 2011.

KNAUSS, Paulo. A festa da imagem: a afirmação da escultura pública no Brasil do século XIX. 19\&20, Rio de Janeiro, v. 5, n. 4, out./dez. 2010. Disponível em: <http://www.dezenovevinte.net/obras/pknauss.htm>.

LANDOWSKI, Eric. Não se brinca com humor: a imprensa política e suas charges. FACE. São Paulo: EDUC, v.4, n.2, p. 64-95, jul./dez.1995.

MAGNO, Luciano. História da caricatura brasileira. Rio de Janeiro: Gala Edições de Arte, 2012.

MARCHETTE, Tatiana Dantas. Corvos nos galhos das acácias: o movimento anticlerical em Curitiba, 1896-1912. Curitiba: Aos Quatro Ventos, 1999.

MÉRIAN, Jean-Yves. Aluísio Azevedo, vida e obra: (1857-1913). Rio de Janeiro: Espaço e Tempo/Banco Sudameris - Brasília: INL, 1988

MOTTA, Rodrigo Patto Sá. Jango e o golpe de 1964 na caricatura. Rio de Janeiro: Jorge Zahar, 2006 
NEVES, Margarida de Souza \& HEIZER, Alda. A ordem é o progresso: o Brasil de 1870 a 1910. São Paulo: Atual, 1991.

PAULA, João Antônio de. O processo econômico. IN: CARVALHO, J. M. de. A construção Nacional (1830-1889). Rio de Janeiro: Objetiva, 2012, pp. 179-223.

PINHEIRO, Amalio. Aquém da identidade e da oposição: formas na cultura mestiça. Piracicaba: Unimep, 1994.

REZENDE, Lívia Lazzaro. A circulação de imagens no Brasil Oitocentista: uma história com marca registrada. In. CARDOSO, Rafael (Org.) $O$ design brasileiro antes do design: aspectos da história gráfica 1870-1960. São Paulo: Cosac Naify, 2005.

RIVERS, Kenneth T. Transmutations. Understanding Literary and Pictorial Caricature. Lanham, Maryland: London: University Press of America, 1991.

SALIBA, Elias Thomé. A dimensão cômica da vida privada na República. In SEVCENKO, N. org. História da vida privada no Brasil. República: da Belle Epoque à Era do Rádio. São Paulo: Companhia das Letras, 1998, p. 289-365.

SCHWARCZ, Lilia Moritz. As barbas do imperador. D. Pedro II, um monarca nos trópicos. São Paulo: Companhia das Letras, 1998.

TURAZZI, Maria Inez. Poses e trejeitos. A fotografia e as exposições na era do espetáculo (1839-1889). Petrópolis: Funarte/Ed. Rocco, 1995.

Recebido em 30/06/2016 Aprovado em 26/08/2016

Universidade do Estado de Santa Catarina - UDESC

Programa de Pós-Graduação em História - PPGH

Revista Tempo e Argumento Volume 08 - Número 18 - Ano 2016 tempoeargumento@gmail.com 